\title{
EVALUASI KEMAMPUAN SISTEM PENDINGIN REAKTOR SETELAH REVITALISASI MENARA PENDINGIN
}

\section{EVALUATION OF THE CAPABILITY OF THE REACTOR COOLING SYSTEM AFTER REVITALIZING THE COOLING TOWER}

\author{
Sukarno Sigit ${ }^{1}$, Susanto ${ }^{2}$, Sukiyanto ${ }^{3}$, Banyu Rizki Fauzan ${ }^{4}$ \\ 1.2.3,4PRSG-BATAN, Kawasan Puspiptek Gd.30, Serpong, 15310 \\ sigit100483@gmail.com
}

Diterima: 10 April 2019, diperbaiki : 7 Mei 2019, disetujui : 13 Mei 2019

\begin{abstract}
ABSTRAK
EVALUASI KEMAMPUAN SISTEM PENDINGIN REAKTOR SETELAH REVITALISASI MENARA PENDINGIN. Sistem pendingin RSG-GAS terdiri dari sistem pendingin primer dan sekunder. Sistem pendingin primer berfungsi untuk mengambil panas dari teras reaktor sedangkan sistem pendingin sekunder berfungsi untuk mengambil panas sistem pendingin primer melalui heat exchanger dan melepasnya ke lingkungan. Sistem pendingin reaktor telah beroperasi lebih dari 28 tahun sehingga perlu dilakukan revitalisasi. Salah satu bagian yang diganti adalah menara pendingin. Kemampuan sistem pendingin reaktor setelah revitalisasi dapat diketahui melalui perbandingan daya kalorimetri sistem pendingin sekunder dan primer serta membandingkan temperatur masuk ( $\left.T_{\text {inlet }}\right)$ dan keluar ( $\left.T_{\text {outlet}}\right)$ sistem pendingin reaktor dengan nilai desainnya. Dari hasil perbandingan menunjukan perubahan daya kalorimetri di sisi primer sebanding dengan perubahan daya kalorimetri sisi sekunder. Hal ini menunjukan tranfer panas dari sistem pendingin primer ke sekunder dan proses pelepasan panas ke lingkungan berjalan dengan baik. Untuk hasil perbandingan $T_{\text {inlet }}-T_{\text {outlet }}$ pendingin reaktor pada daya penuh $30 \mathrm{MW}$, $T_{\text {inlet }}-T_{\text {outlet }}$ sistem pendingin primer dan sekunder tidak melampaui nilai batas maksimal desain. Dari semua perbandingan menunjukan menara pendingin baru sistem pendingin sekunder memberikan tingkat kemampuan pembuangan panas yang lebih baik pada saat reaktor beroperasi.
\end{abstract}

Kata kunci: Reaktor RSG-GAS, sistem pendingin reaktor, daya kalorimetri.

\section{ABSTRACT}

EVALUATION OF THE CAPABILITY OF THE REACTOR COOLING SYSTEM AFTER REVITALIZING THE COOLING TOWER. The RSG-GAS cooling system consists of primary and secondary cooling systems. The primary cooling system functions to take heat from the reactor core while the secondary cooling system serves to take heat from the primary cooling system through a heat exchanger and release it to the environment. The reactor coolant system has been operating for more than 28 years so it needs revitalization. One part that is replaced is the cooling tower. The reactor coolant system capability after revitalization can be seen through the comparison of secondary and primary cooling system calorimetry power and comparing the Tinlet and Toutlet reactor coolant systems with their design values. From the results of the comparison, the change in calorimetry power on the primary side is proportional to the change in the secondary 
side calorimetry power. This shows the heat transfer from the primary to the secondary cooling system and the process of releasing heat to the environment goes well. For a comparison of the reactor coolant Tinlet-Outline at full power of $30 \mathrm{MW}$, the Tinlet-Outflow of primary and secondary cooling systems does not exceed the maximum design limit value. From all comparisons showing a new cooling tower the secondary cooling system provides a better level of heat dissipation when the reactor operates.

\section{Keywords: RSG-GAS reactor, reactor coolant system, calorimetry power.}

\section{PENDAHULUAN}

Reaktor Serba Guna G.A. Siwabessy (RSG-GAS) Badan Tenaga Nuklir Nasional (BATAN) merupakan reaktor riset jenis Material Testing Reaktor (MTR) pertama di dunia yang dioperasikan langsung dengan menggunakan bahan bakar dengan pengkayaan uranium rendah, low enriched uranium (LEU) [1]. Reaktor Serba Guna G.A.Siwabessy (RSG-GAS) memiliki 2 sistem pendingin yaitu sistem pendingin primer dan sistem pendingin sekunder. Sistem pendingin primer berfungsi menyerap panas dari teras reaktor dan sistem pendingin sekunder berfungsi menyerap panas dari sistem pendingin primer melalui penukar panas (heat exchanger). Reaktor RSG-GAS memiliki 2 penukar panas (JE-01 BC01/BC-02). Tiap penukar panas disiapkan untuk memindahkan $50 \%$ dari beban total pemindahan panas primer pada operasi reaktor dengan daya penuh, walaupun begitu untuk pengoperasian reaktor di bawah $50 \%$ daya penuh tetap menggunakan 2 penukar panas. Kedua penukar panas berjenis sel dan pipa (shell-and-tube type). Air sekunder mengalir melalui pipa-pipa dan air pendingin primer mengalir di sekeliling pipa-pipa pada sisi sel dengan arah berlawanan [2]. Salah satu komponen penting dari sistem pendingin sekunder adalah menara pendingin yang berfungsi melepas panas yang diserap dari penukar panas ke lingkungan. Kemampuan menara pendingin telah mengalami penurunan ditandai dengan $T_{\text {inlet }}-T_{\text {outlet }}$ sistem pendingin primer dan sekunder yang melampaui nilai desain pada saat operasi daya penuh $30 \mathrm{MW}$ pada tanggal 15 Mei 2018 (teras 96) untuk beberapa rentang daya ${ }^{[3]}$. Oleh karena itu menara pendingin telah direvitalisasi pada bulan oktober sampai dengan Desember 2018 yaitu dengan mengganti komponen blower, filter dan lainnya serta merubah arah semburan. Pengujian kemampuan menara pendingin baru telah dilaksanakan pada tanggal 20 Desember 2018. Tujuan penulisan karya tulis ilmiah ini adalah untuk mengetahui kemampuan pembuangan panas sistem pendingin reaktor setelah revitalisasi.

Kemampuan menara pendingin sistem pendingin reaktor dapat dianalisa dengan membandingkan daya kalorimetri sistem pendingin primer dan sekunder pada saat operasi daya penuh $30 \mathrm{MW}$ secara bertahap. Daya kalorimetri sistem pendingin primer dan sekunder dapat dihitung dengan persamaan daya kalorimetri yang terdapat pada buku tabel 
konversi daya reaktor. Pada sisi sekunder faktor-faktor yang mempengaruhi besarnya daya kalorimetri adalah laju alir sistem pendingin sekunder dan beda temperatur masuk ( $\left.T_{\text {inlet}}\right)$ dan keluar

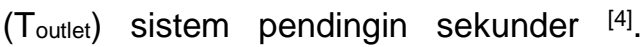
Untuk sistem pendingin primer faktorfaktor yang mempengaruhi besarnya perhitungan daya kalorimetri adalah perbedaan laju alir sistem pendingin primer dan beda temperatur masuk ( $\mathrm{T}_{\text {inlet}}$ ) dan keluar (Toutlet) teras reaktor. Selain melalui itu kemampuan sistem pendingin reaktor dapat dianalisa dengan membandingkan $\mathrm{T}_{\text {inlet }} \quad-\mathrm{T}_{\text {outlet }}$ sistem pendingin primer dan sekunder pada saat reaktor beroperasi daya penuh $30 \mathrm{MW}$ dengan nilai desain yang tercantum pada LAK RSG Rev 10.1.

\section{LANDASAN TEORI}

Sistem Pendingin Primer
Sistem pendingin primer mengambil panas dari teras dan reflektor. Sistem tersebut didesain untuk beban pemindahan panas nominal $32.400 \mathrm{~kW}$ pada laju alir masa total $860 \mathrm{~kg} /$ detik. Pada temperatur desain udara luar $28^{\circ} \mathrm{C}$, temperatur inlet/outlet teras adalah 40,2 ${ }^{\circ} \mathrm{C} / 48,9{ }^{\circ} \mathrm{C}$ dengan kondisi reaktor beroperasi pada daya penuh. Laju alir pendingin primer minimum adalah 800 $\mathrm{kg} /$ detik. Aliran pendingin primer tetap (tidak diubah), dan selama sistem beroperasi normal dengan dua pompa primer dioperasikan. Apabila temperatur udara luar menyimpang dari $28{ }^{\circ} \mathrm{C}$, temperatur inlet teras akan mengikutinya secara linier dari harga $40,2^{\circ} \mathrm{C}$. Harga batas atas diberlakukan pada temperature outlet penukar panas yang dikirim ke Sistem Proteksi Reaktor (SPR) dan dapat memadamkan reaktor. Diagram sistem pendingin reaktor seperti pada Gambar1 dan data desain sistem pendingin primer yang berkaitan dengan tulisan ini dirangkum pada Tabel 1.

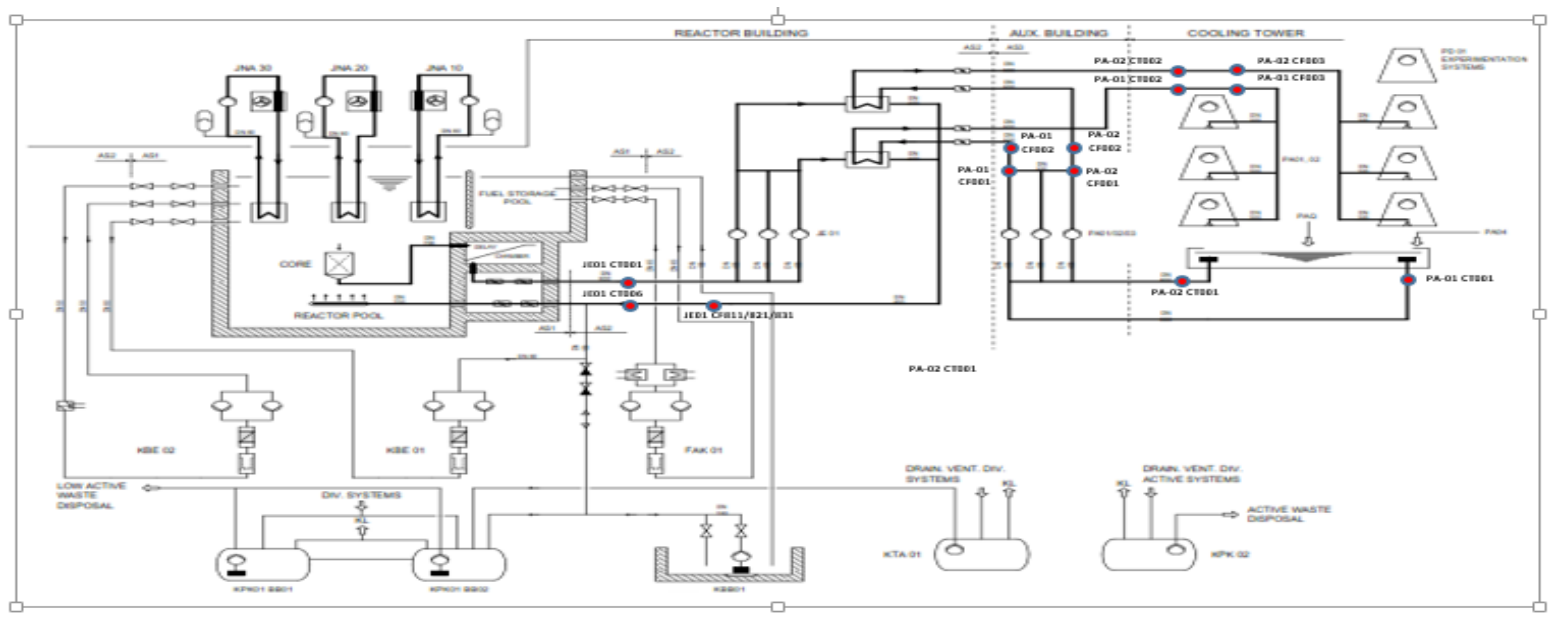

Gambar 1. Diagram sistem pendingin reaktor [5] 
Tabel 1. Data desain sistem pendingin primer [6]

\begin{tabular}{ll}
\hline $\begin{array}{l}\text { Parameter } \\
\text { Desain }\end{array}$ & Nilai \\
\hline Tekanan & $10 \mathrm{bar}$ \\
\hline Temperatur Desain & $60{ }^{\circ} \mathrm{C}$ \\
\hline Laju Alir Masa Nominal & $860 \mathrm{~kg} / \mathrm{detik}$ \\
\hline Kemampuan Membuang Panas (di luar Experimen & $32.400 \mathrm{~kW}$ \\
\hline Temperatur Inlet Teras (temperatur udara luar $\left.28^{\circ} \mathrm{C}\right)$ & $40,2^{\circ} \mathrm{C}$ \\
\hline Temperatur outlet teras & $48,9^{\circ} \mathrm{C}$ \\
\hline Laju alir tiap pompa & $1.570 \mathrm{~m}^{3} / \mathrm{jam}$ \\
\hline
\end{tabular}

Terdapat 3 sistem pengukur laju alir sistem pendingin primer yaitu JE01 CF811, JE01 CF821 dan JE01 CF831. Tampilan sistem tersebut dalam skala $\mathrm{m}^{3} / \mathrm{jam}$.

\section{Sistem Pendingin Sekunder}

Panas sistem pendingin primer diambil oleh sistem pendingin sekunder melalui penukar panas. Sistem pendingin sekunder memiliki kapasitas pemindahan panas nominal $38.000 \mathrm{~kW}$. Data desain sistem pendingin sekunder yang berkaitan dengan tulisan ini dirangkum pada Tabel 2.

Tabel 2. Data desain sistem pendingin sekunder [6]

\begin{tabular}{ll}
\hline Parameter & Nilai desain \\
\hline Tekanan & 6 bar \\
\hline Temperatur Desain & $60{ }^{\circ} \mathrm{C}$ \\
\hline Kapasitas (di dalam experiment) & $38.000 \mathrm{~kW}$ \\
\hline Laju Alir desain (di luar experiment) & $3.900 \mathrm{~m}^{3} / \mathrm{jam}$ \\
\hline Jumlah pompa sirkulasi & $3 \times 50 \%$ \\
\hline Laju alir tiap pompa & $1.950 \mathrm{~m}^{3} / \mathrm{jam}$ \\
\hline Temperatur udara luar & $28{ }^{\circ} \mathrm{C}$ \\
\hline $\begin{array}{l}\text { Temperatur aliran balik ke menara pendingin (di dasar } \\
\text { menara) }\end{array}$ & $32{ }^{\circ} \mathrm{C}$ \\
\hline
\end{tabular}

Sistem sekunder mempunyai kapasitas untuk mengambil panas total sebesar $38 \mathrm{MW}$ (tidak termasuk pendingin untuk eksperimen). Sistem sekunder terdiri dari $2 \times 50 \%$ bagian (pompapompa, dua penukar panas, saluran pipa dan blok-blok menara pendingin). Dua blok menara pendingin yang paralel masing-masing terdiri dari 3 modul menara pendingin. Selain itu disediakan modul (modul ketujuh) di atas kolam menara pendingin yang sama untuk membuang panas tambahan yang berasal dari eksperimen di dalam kolam 
reaktor. Data desain menara pendingin yang berkaitan dengan tulisan ini ditunjukkan pada Tabel 3.

Tabel 3. Data desain menara pendingin [6]

\begin{tabular}{ll}
\hline Parameter & Nilai \\
\hline Jumlah modul menara pendigin (di luar eksperimen) & 6 \\
\hline Kapasitas tiap modul & $5.500 \mathrm{~kW}$ \\
\hline Kapasitas desain & $33.000 \mathrm{~kW}$ \\
\hline Jumlah unit pararel & $2 \times 50 \%$ \\
\hline Kapasitas perunit & $16.500 \mathrm{~kW}$ \\
\hline Temperatur air inlet & 39,2 \\
\hline Temperatur air outlet & 32,02 \\
\hline
\end{tabular}

\section{Daya Kalorimetri Reaktor}

Perhitungan daya kalorimetri merupakan perhitungan daya berdasarkan perbedaan temperatur untuk sistem berfluida dengan laju alir tetap. Reaktor RSG-GAS merupakan reaktor berfluida dengan laju alir tetap. Untuk sistem pendingin primer jumlah panas yang dipindahkan dari teras reaktor ke pendingin diketahui dari perbedaan temperatur pendingin yang keluar teras reaktor (JE01 CT001) dan yang masuk ke dalam teras reaktor (JE01 CT006) dengan laju alir pendingin primer dan sistem purifikasi kolam reaktor tetap [7]. Sedangkan untuk pendingin sekunder jumlah panas yang diserap dari teras reaktor diketahui dari perbedaan temperatur pendingin sekunder sebelum menara pendingin (PA01/02 CT002), $T_{\text {outlet }}$ pendingin sekunder) dan temperatur sesudah menara pendingin (PA01/02 CT001), Tinlet pendingin sekunder) dengan laju alir sistem pendingin sekunder tetap.
Besarnya daya kalorimetri reaktor dapat dihitung dengan Persamaan $1^{[8]}$.

$Q=W x \rho \times \mathrm{Cp} \times \Delta \mathrm{T}$

$\Delta T=$ Tin - Tout

$T b=\frac{\text { Tin }+ \text { Tout }}{2}$

Keterangan

$\mathrm{Q}=$ daya thermal reaktor $(\mathrm{kW})$

$\mathrm{W}=$ laju alir sistem pendingin primer / sekunder ( $\mathrm{m}^{3} /$ jam)

$\rho=$ kerapatan (densitas pendingin primer dan sekunder) $\left(\mathrm{kg} / \mathrm{m}^{3}\right)$

$\Delta \mathrm{T}=$ beda $\mathrm{T}_{\text {outlet }}$ dan $\mathrm{T}_{\text {inlet }}\left({ }^{\circ} \mathrm{C}\right)$

$\mathrm{Tin}=\mathrm{T}_{\text {inlet }}$ sistem pendingin primer $/$ sekunder reaktor $\left({ }^{\circ} \mathrm{C}\right)$

Tout $=\mathrm{T}_{\text {outlet }}$ sistem pendingin primer /sekunder reaktor $\left({ }^{\circ} \mathrm{C}\right)$

$\mathrm{Cp}=$ panas spesifik pendingin sistem pendingin primer /sekunder (KW. $\mathrm{det} / \mathrm{kg}^{\circ} \mathrm{C}$ )

$\mathrm{Tb}=$ rerata $\mathrm{T}_{\text {outlet }}$ dan $\mathrm{T}_{\text {inlet }}$ sistem pendingin primer/ sekunder $\left({ }^{\circ} \mathrm{C}\right)$

Laju alir sistem pendingin primer dihitung dari jumlah air yang terukur pada sensor JE01 CF811/821/831 dan sistem 
purifikasi kolam reaktor KBE01 CF003. Sedangkan laju pendingin sekunder dihitung dari rata-rata jumlah air yang terukur pada sensor PA01/02 CF001/002/003. Sedangkan untuk panas spesifik dan kerapatan pendingin reaktor dapat dihitung dengan menggunakan Persamaan 4 dan $5^{[8]}$.

$\rho=1000 \times\left(1,0029-1,5838 \times 10^{-4} \times \mathrm{Tb}\right.$

$\left.-2,847 \times 10^{-6} \times \mathrm{Tb}^{2}\right)$

$\mathrm{C}_{\mathrm{p}}=4,167+0,05^{(-0,0734 \times \mathrm{Tb})}+0,0031 \times$ $\mathrm{e}^{(0,0268 \times \mathrm{Tb})}$

Perhitungan daya kalorimetri sistem pendingin primer sekunder dilakukan 2 kali perhitungan karena terdiri dari 2 jalur unit pendingin seperti pada Persamaan 6 [9].

$$
Q s=Q 1+Q 2
$$

\section{Dimana}

$Q_{s}=$ Daya kalorimetri total sistem pendingin sekunder

Q1 = Daya kalorimteri jalur 1 sistem pendingin sekunder

Q2 = Daya kalorimteri jalur 2 sistem pendingin sekunder

Besarnya daya kalorimetri sisi primer sebanding panas yang diserap oleh sistem pendingin sekunder dan besarnya daya kalorimetri sistem pendingin sekunder sebanding panas yang dilepas ke lingkungan oleh menara pendingin. Idealnya perubahan daya kalorimetri primer sebanding dengan perubahan daya kalorimetri sekunder, hal ini menunjukan jumlah kalor yang diserap oleh sistem pendingin sekunder sebanding dengan jumlah kalor yang dilepas ke lingkungan [10].

\section{METODOLOGI}

Dalam rangka menguji menara pendingin baru dilakukan operasi reaktor $30 \mathrm{MW}$ secara bertahap. Pengambilan data dilakukan pada saat operasi $30 \mathrm{MW}$ tanggal 20 Desember 2018 teras 97. Setelah daya mencapai daya $30 \mathrm{MW}$ dipertahankan selama 10 jam. Berdasarkan instruksi operasi nomor : RSG.OR.IO.97/05-F/2018, sistem-sistem yang dioperasikan antara lain :

1. Sistem pendingin primer JE01 AP001 dan AP003

2. Sistem pendingin sekunder PA01 dan PA02 AP001

3. Menara pendingin cooling tower PA01 AH001/002 dan PA02 AH001/002

4. Sistem purifikasi air kolam reaktor KBE01 AP001 dan AP002

5. Sistem purifikasi dan lapisan air hangat KBE02 AP001

6. Sistem pendukung lainnya

Untuk pengoperasian $30 \mathrm{MW}$ dilakukan dengan mengoperasikan 6 menara pendingin sehingga dilakukan penambahan menara pendingin yaitu PA01 AH003 dan PA02 AH003. Penambahan menara pendingin dilakukan ketika daya dinaikan ke $30 \mathrm{MW}$ secara bertahap.

Tata kerja yang dilakukan untuk mendapatkan nilai daya kalorimetri sistem pendingin reaktor dan kesesuaian $\mathrm{T}$ inlet Toutlet dengan nilai desain pada pengoperasian reaktor RSG-GAS pada teras 97 dengan daya maksimum $30 \mathrm{MW}$, adalah: 
1. Mencatat data yang berkaitan dengan sistem pendingin primer dan sekunder pada panel tegak (daya reaktor awal $15 \mathrm{MW})$.

2. Menaikan daya reaktor (manuver daya) dan mengkritiskan pada daya yang dikehendaki.

3. Mencatat parameter yang berkaitan dengan sistem pendingin primer dan sekunder setelah daya stabil $( \pm 15$ menit).

4. Lakukan langkah poin $1 \mathrm{~s} / \mathrm{d} 4$ untuk tingkat daya lainnya sampai dengan daya maksimum $30 \mathrm{MW}$.

5. Padamkan reaktor.

6. Menggunakan data-data yang telah dicatat untuk menghitung daya kalorimetri sistem pendingin primer, sekunder dan membandingkannnya.

7. Membandingkan Tin-Tout sistem pendingin primer dan sekunder dengan nilai desainnya berdasarkan LAK RSG-GAS Rev 10.1.

\section{HASIL DAN PEMBAHASAN}

Berikut ini hasil pencatatan data dan pembahasan yang telah dilakukan di RSG-GAS pada tanggal 20 Desember 2018 (teras 97) dengan contoh perhitungan daya kalorimetri sistem pendingin sekunder dan perhitungan daya kalorimetri primer dapat dilakukan dengan cara yang sama. Hasil perhitungan untuk semua rentang daya seperti pada Tabel 5.

Tabel 4. Data pendingin primer dan sekunder pada saat operasi $30 \mathrm{MW}$

\begin{tabular}{|c|c|c|c|c|c|c|c|c|c|}
\hline Daya & & Sitem Pel & dingin Primer & & & Sitem $P$ & ndingin & ekunder & \\
\hline Reaktor & $\begin{array}{c}\mathrm{T} \\
\text { Outlet }\end{array}$ & $\mathrm{T}$ Inlet & JE01 & $\mathrm{T}$ inlet & T inlet & $\begin{array}{c}\mathrm{T} \\
\text { outlet }\end{array}$ & $\begin{array}{c}\mathrm{T} \\
\text { outlet }\end{array}$ & $\begin{array}{c}\text { PA01 } \\
\text { CF001/002/ } \\
003\end{array}$ & $\begin{array}{c}\text { PA02 } \\
\text { CF001/002/ } \\
003\end{array}$ \\
\hline$(\mathrm{MW})$ & $\begin{array}{c}\text { JE01 } \\
\text { CT001 } \\
\left({ }^{\circ} \mathrm{C}\right)\end{array}$ & $\begin{array}{c}\text { JE01 } \\
\text { CT006 } \\
\left({ }^{\circ} \mathrm{C}\right)\end{array}$ & $\begin{array}{c}\text { CF811/821/831 } \\
\text { m3/jam }\end{array}$ & $\begin{array}{c}\text { PA01 } \\
\text { CT001 } \\
(\stackrel{\circ}{C})\end{array}$ & $\begin{array}{l}\text { PA02 } \\
\text { CT001 } \\
(\stackrel{\circ}{ } \text { C) }\end{array}$ & $\begin{array}{c}\text { PA01 } \\
\text { CT002 } \\
\left({ }^{\circ} \text { C }\right)\end{array}$ & 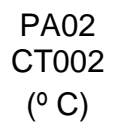 & m3/jam & m3/jam \\
\hline 5 & 26 & 25 & 3150 & 26 & 26 & 25 & 25 & $1950-2050$ & $2000-2050$ \\
\hline 10 & 28 & 26 & 3150 & 27 & 27 & 25 & 25 & $1950-2050$ & $2000-2050$ \\
\hline 15 & 30 & 27 & 3150 & 28 & 28 & 26 & 26 & $1950-2050$ & $2000-2050$ \\
\hline 20 & 32 & 28 & 3150 & 29 & 29 & 26 & 26 & $1950-2050$ & $2000-2050$ \\
\hline 25 & 36 & 30 & 3150 & 32 & 32 & 27 & 27 & $1950-2050$ & $2000-2050$ \\
\hline 30 & 44 & 36 & 3150 & 38 & 38 & 31 & 31 & $1950-2050$ & $2000-2050$ \\
\hline
\end{tabular}

Data operasi 30 MW RSG-GAS ditampilkan pada Tabel 4, data-data tersebut meliputi $\mathrm{T}_{\text {inlet }}-\mathrm{T}_{\text {outlet }}$ sistem pendingin primer (JE01 CT001, JE01 CT006), laju alir sistem pendingin primer (JE01 CF811/821/ 831), $\mathrm{T}_{\text {inlet }}-\mathrm{T}_{\text {outlet }}$ sistem pendingin sekunder (PA01/02 CT001/002) dan laju alir sistem pendingin sekuder (PA01/02 CF001/002/003).Dari Tabel 4 diketahui rata-rata laju alir sistem pendingin primer sebesar $3.150 \mathrm{~m}^{3} / \mathrm{jam}$, nilai tersebut di atas batas minimal yaitu 
sebesar $2.902 \mathrm{~m}^{3} / \mathrm{jam}$ dan di bawah batas maksimal yaitu sebesar $3.200 \mathrm{~m}^{3} / \mathrm{jam}$. Selain itu diketahui laju alir sistem pendingin sekunder berflutktuasi dari 1950-2050 $\mathrm{m}^{3} / \mathrm{jam}$ dengan nilai rata-rata 1.983,33 $\mathrm{m}^{3} / \mathrm{jam}$ untuk jalur 1 dan 2.016,67 $\mathrm{m}^{3} / \mathrm{jam}$ untuk jalur 2. Nilai tersebut tidak terlalu jauh dari nilai desainnya sebesar $1.950 \quad \mathrm{~m}^{3} / \mathrm{jam}$. Selanjutnya data-data tersebut akan diolah untuk perhitungan daya kalorimetri sistem pendingin primer dan sekunder.

Tabel 5. Daya Kalorimetri Sistem Pendingin Primer dan Sekunder

\begin{tabular}{ccc}
\hline $\begin{array}{c}\text { Daya } \\
\text { Yang } \\
\begin{array}{c}\text { Dikehendaki } \\
(\mathrm{MW})\end{array}\end{array}$ & $\begin{array}{c}\text { Daya } \\
\text { kalorimetri } \\
\text { Primer } \\
(\mathrm{MW})\end{array}$ & $\begin{array}{c}\text { Daya } \\
\text { kalorimetri } \\
\text { Sekunder } \\
(\mathrm{MW})\end{array}$ \\
\hline 5 & 3.46 & 4.40 \\
\hline 10 & 7.11 & 9.03 \\
\hline 15 & 10.75 & 9.03 \\
\hline 20 & 14.38 & 13.65 \\
\hline 25 & 21.64 & 22.89 \\
\hline 30 & 28.84 & 32.08 \\
\hline \multicolumn{3}{c}{ Rata-rata } \\
\hline
\end{tabular}

Contoh perhitungan daya kalorimetri pendingin sekunder

Diketahui

Daya nominal : $5 \mathrm{MW}$

Toutlet jalur 1 (PA01 CT02) : $26^{\circ} \mathrm{C}$

Toutlet jalur 2 (PA02 CT02) : $26^{\circ} \mathrm{C}$

Tinlet jalur 1 (PA01 CT01) : $26^{\circ} \mathrm{C}$

Tinlet jalur 2 (PA02 CT01) : $25^{\circ} \mathrm{C}$

Laju alir pendingin sekunder jalur 1 (ratarata PA01 CF001-003) $=1983.33 \mathrm{~m}^{3} / \mathrm{jam}$

$=0.5509 \mathrm{~m}^{3} /$ detik

Laju alir pendingin sekunder jalur 2 (ratarata PA02 CF001-003) $=2016.67 \mathrm{~m}^{3} / \mathrm{jam}$ $=0.5601 \mathrm{~m}^{3} /$ detik
Faktor Koreksi $=0.05$ Ditanyakan $Q$ kalorimetri sistem pendingin sekunder Karena Tinlet dan outlet jalur satu dan dua sama maka $\Delta T, T b, \rho, C_{p}$ bernilai sama

$\Delta \mathrm{T}$ Jalur1\&2 =

Toutlet - Tinlet - Faktor Koreksi

$$
\begin{aligned}
& =26-25-0.05 \\
& =0.95
\end{aligned}
$$

$\rho$ jalur $1 \& 2=1000 \times(1,0029-1,5838 x$ $\left.10^{-4} \times \mathrm{Tb}-2,847 \times 10^{-6} \times \mathrm{Tb}^{2}\right)$ $=1000 \times\left(1,0029-1,5838 \times 10^{-4} \times 25.5-\right.$ $\left.2,847 \times 10^{-6} \times 25.5^{2}\right) \quad=997.01 \mathrm{~kg} / \mathrm{m}^{3}$

$$
\begin{aligned}
& \mathrm{C}_{p}=4,167+0,05^{(-0,0734 \times \mathrm{Tb})}+0,0031 \mathrm{x} \\
& \mathrm{e}^{(0,0268 \times \mathrm{Tb})} \\
& \quad=4,167+0,05^{(-0,0734 \times 25.5)}+0,0031 \mathrm{x} \\
& \mathrm{e}^{(0,0268 \times 25.5)} \\
& \quad=4.18 \mathrm{~kW} \cdot \operatorname{det} / \mathrm{kg}^{\circ} \mathrm{C}
\end{aligned}
$$

$\mathrm{Q}$ kalorimetri Jalur satu $=W x \rho \times \mathrm{Cp} \times \Delta \mathrm{T}$ $=0.5509 \times 997.01 \times 4.18 \times 0.95$

$=2.18 \mathrm{MW}$

$\mathrm{Q}$ kalorimetri Jalur dua $=W x \rho \times \mathrm{Cp} \times \Delta \mathrm{T}$ $=0.5601 \times 997.01 \times 4.18 \times 0.95$

$=2.22 \mathrm{MW}$

$\mathrm{Q}$ Kaliorimetri total $=\mathrm{Q}$ kalorimetri Jalur satu $+Q$ kalorimetri Jalur dua $=4.4 \mathrm{MW}$

Dari Tabel 5 didapat hasil perhitungan daya kalorimetri pendingin sekunder dan primer. Daya kalorimetri sistem pendingin 
sekunder merupakan perhitungan daya berdasarkan perbedaan $\mathrm{T}_{\text {outlet }}$ dan $\mathrm{T}_{\text {inlet }}$ dengan laju alir fluida yang tetap. Jumlah total daya kalorimetri sistem pendingin sekunder merupakan penjumlahan daya kalorimetri jalur 1 dan jalur 2. Sedangkan daya kalorimetri sistem pendingin primer dihitung $\mathrm{T}_{\text {outlet }}$ dan $\mathrm{T}_{\text {inlet }}$ dengan laju alir fluida tetap. Perbandingan daya kalorimetri sistem pendingin primer dan sekunder seperti pada Gambar 2.

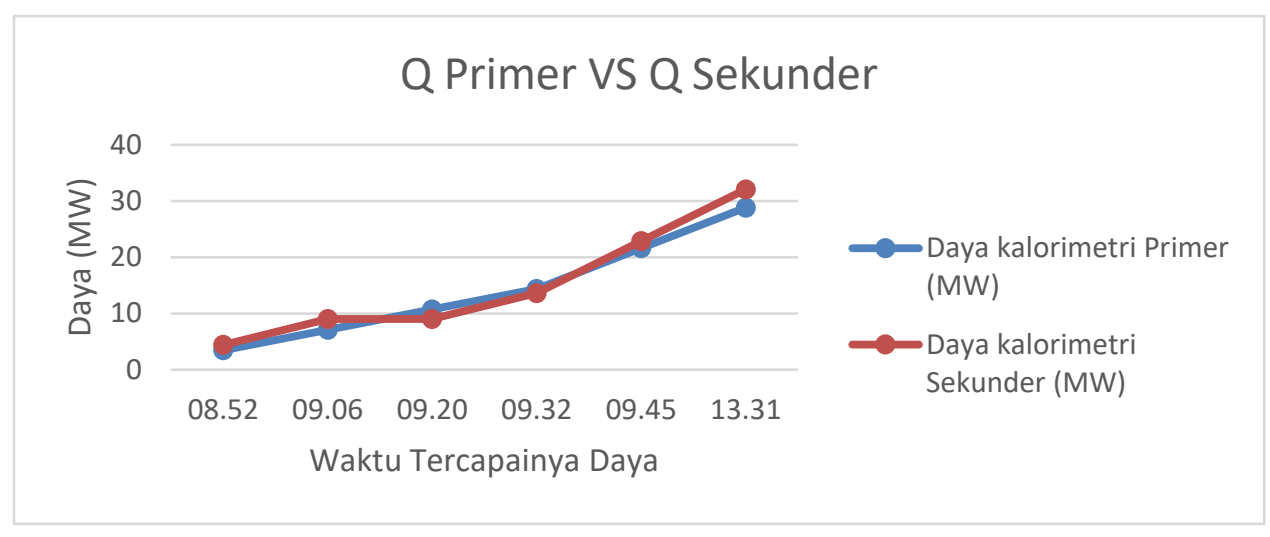

Gambar 2. Daya kalorimetri primer vs sekunder menggunakan menara pendingin baru

Dari perbandingan daya kalorimetri daya kalorimetri sisi sekunder. Hal ini sistem pendingin primer dan sekunder menunjukan panas yang diserap dari yang ditampilkan pada Gambar 2 sistem pendingin primer sebanding menunjukan perubahan daya kalorimetri dengan panas yang dilepas ke sisi primer sebanding dengan perubahan lingkungan.

Tabel 6. Tabel perbandingan nilai parameter sistem pendingin primer dan sekunder pada saat daya penuh $30 \mathrm{MW}$

\begin{tabular}{lccl}
\hline \multicolumn{1}{c}{ Parameter } & $\begin{array}{c}\text { Hasil } \\
\text { pengukuran } \\
\left({ }^{\circ} \mathbf{C}\right)\end{array}$ & $\begin{array}{c}\text { Nilai Batas } \\
\text { desain } \\
\left({ }^{\circ} \mathrm{C}\right)\end{array}$ & Keterangan \\
\hline JE01 CT001 (T Outlet) & 44.00 & 48.9 & Aman \\
\hline JE01 CT006 (T inlet) & 36.00 & 40.2 & Aman \\
\hline & & & \\
\hline $\begin{array}{l}\text { Sistem pendingin } \\
\text { sekunder }\end{array}$ & & & \\
\hline PA01 CT001 (T Oulet) & 38.00 & 39.2 & Aman \\
\hline PA02 CT001 (T Outlet) & 38.00 & 39.2 & Aman \\
\hline PA01 CT002 (T Inlet) & 31.00 & 32 & Aman \\
\hline PA02 CT002 (T inlet) & 31.00 & 32 & Aman \\
\hline
\end{tabular}


Selain itu dari Tabel 6 terlihat kemampuan menara pendingin dalam menjaga temperatur inlet dan outlet sistem pendingin sekunder dan primer agar tidak melampaui nilai batas desain pada saat operasi daya penuh $30 \mathrm{MW}$. $\mathrm{T}_{\text {inlet }}$ pendingin primer sebesar $36^{\circ} \mathrm{C}$ tidak melampaui nilai batas desain sebesar $40,2{ }^{\circ} \mathrm{C}$. Toutlet sistem pendingin primer sebesar $44^{\circ} \mathrm{C}$ tidak melampaui nilai batas desain sebesar $48,9{ }^{\circ} \mathrm{C}$. Untuk $\mathrm{T}_{\text {inlet }}$ pendingin sekunder sebesar $31^{\circ} \mathrm{C}$ tidak melampaui nilai batas desain sebesar 32 ${ }^{\circ} \mathrm{C}$ dan untuk $\mathrm{T}_{\text {oulet }}$ nya sebesar $38^{\circ} \mathrm{C}$ tidak melampaui nilai batas desain sebesar $39,2{ }^{\circ} \mathrm{C}$. Dari semua perhitungan dan perbandingan menunjukan menara pendingin baru sistem pendingin sekunder memberikan tingkat kemampuan pembuangan panas yang lebih baik pada saat reaktor beroperasi.

\section{KESIMPULAN}

1. Panas sistem pendingin primer yang diserap oleh sistem pendingin sekunder sebanding dengan panas yang dilepas ke lingkungan oleh menara pendingin-

2. $\mathrm{T}$ inlet - $\mathrm{T}_{\text {outlet }}$ sistem pendingin primer dan sekunder tidak ada yang melebihi nilai desain pada saat dioperasian daya penuh 30 MW.

3. Sistem pendingin reaktor dengan menara pendingin baru memiliki kemampuan yang tinggi dalam mempertahakan temperatur inlet dan outlet pendingin primer dan sekunder di bawah batas maksimal desain berdasarkan LAK RSG-GAS Rev 10.1.

\section{DAFTAR PUSTAKA}

[1] ofil-prsg, diakses pada tanggal 3/02/2019 pukul 06.45

[2] Purbosedjati.A, 1998, Prosiding Seminar Hasil Penelitian PRSG Tahun 1997/1998, ISSN 0854-5278.

[3] Laporan Operasi Reaktor RSG-GAS Daya 30 MW, PRSG-GAS, Mei 2018.

[4] Sigit.S,2018, Digitalisasi Monitor Kanal Pengukuran Daya JKT04 Di Reaktor Serba Guna GA. Siwabessy Berbasis Labview, Teknofisika Nuklir, Sekolah Tinggi Teknologi Nuklir Yogyakarta.

[5] Sukiyanto dkk, 2018, Analisis Pengoperasian Reaktor RSG-GAS Pada Teras 96 Dengan Daya

Maksimum 30 MW, Buletin Pengelolaan Reaktor Nuklir 2018, Nuklir, Yogyakarta.

[6] Laporan Analisis Keselamatan, PRSG-GAS Rev 10.1, Desember 2011.

[7] Sukiyanto, Nurtanto.B, Pengukuran Faktor Koreksi Kalibrasi Daya 15 MW Dan 30 MW Di Reaktor RSGGAS,Buletin Pengelolaan Reaktor Nuklir Vol 14 April 2017.

[8] Isnaeni.D, 1995, Tabel Konversi Daya, BATAN,Serpong.

[9] Pardi, Fauzan.B, Evaluasi Pengoperasian Pompa Sistem Pendingin Sekunder Untuk Menunjang Operasi Reaktor RSG- 
GAS, Buletin Pengelolaan Reaktor Nuklir. Vol. XIV No.1 2017, hal. 4046.
[10] Suparno.Paul, 2018, Modul5 KB1 Temperatur dan Kalor: Kemetrian Riset, Teknologi dan Pendidikan Tinggi. 
Evaluasi Kemampuan Sistem Pendingin...

(Sukarno Sigit, dkk)
p-ISSN:0216-2695, e-ISSN:2614-8943

http://jurnal.batan.go.id/idex/php/bprn 
Buletin Pengelolaan Reaktor Nuklir

Bulletin of Nuclear Reactor Management

Vol. XVI , No.1, April 2019:hal. 29-39 
Evaluasi Kemampuan Sistem Pendingin...

(Sukarno Sigit, dkk)
p-ISSN:0216-2695, e-ISSN:2614-8943

http://jurnal.batan.go.id/idex/php/bprn 
Buletin Pengelolaan Reaktor Nuklir

Bulletin of Nuclear Reactor Management

Vol. XVI, No.1, April 2019:hal. 29-39 
Evaluasi Kemampuan Sistem Pendingin...

(Sukarno Sigit, dkk)
p-ISSN:0216-2695, e-ISSN:2614-8943

http://jurnal.batan.go.id/idex/php/bprn 